\title{
Pandemic and Pedagogy: Elementary School Teachers' Experience of H1N1 Influenza in the Classroom
}

Patrick Howard, PhD., Education Department, Cape Breton University, Nova Scotia Email:patrick_howard@cbu.ca

Joy Howard, BN, RN, Clinical Trials, Cape Breton District Health Authority, Nova Scotia

Email: howardjoy@cbdha.nshealth.ca

\section{Abstract}

This study examined elementary school teachers' experience of pandemic preparedness efforts by provincial and local agencies in Nova Scotia, Canada during the 2009 H1N1 flu pandemic. Eleven (11) elementary teachers were surveyed and interviewed and their responses analyzed to determine themes that have pedagogical significance for both education and health promotion. Teachers surveyed experienced a profound sense of responsibility for the children for whom they act in loco parentis. Teachers perceived themselves to be infection control agents and acted on behalf of students to mitigate the spread of the disease. Due to the unique relationship between elementary teachers and children there were high levels of fear and anxiety experienced. Teachers felt fearful for their personal safety and for the health and well-being of their students and reported high levels of anxiety in children. Elementary teachers, who are on the front line of pandemic response, need to be central to administrative efforts to prepare, educate and provide training for those in contact with a high number of vulnerable populations. Further research is required on the experiences of middle school, secondary teachers and principals at all levels of schooling.

\section{Introduction}

Elementary school teachers play an important role in pandemic preparedness and response efforts in Canada. Teachers are instrumental in implementing strategies to reduce the impact and spread of influenza during a pandemic (Cauchemez et al, 2009; Stephenson, 2009). Collectively, teachers have direct contact with thousands of children on a daily basis as well as with thousands more parents and family members. Despite 
this, no research is available on teachers' experiences of being health protective resources in the classroom (Wong, et. al., 2010).

This research project was designed to better understand how government health departments and school district initiatives, created to prevent the spread of the H1N1 virus, were experienced by teachers in the elementary classroom. A clearer understanding of how influenza prevention was experienced at the classroom level may provide important insights which could contribute to more effective pandemic preparedness strategies in the future. To better understand the experience of classroom teachers at the time of the H1N1 flu outbreak it is necessary to contextualize the experience within social, cultural, and institutional factors that appeared important in shaping the experience of teachers. As such, the article begins with a brief history of the virus, and a short overview of pandemic planning across important organizational entities including provincial health departments, the teachers' union, school boards and schools. The paper then examines the teachers' experience of acting as health protective resources, specifically, infection control agents in the elementary school classroom during this particular H1N1 flu pandemic.

The research employed phenomenological methods to elicit the perceptions, attitudes, beliefs and experiences of eleven (11) elementary school teachers working during the H1N1 outbreak in fall 2009 in the Canadian province of Nova Scotia. Participants were chosen from those who responded to an online invitation. A survey, in the form of a questionnaire, was used and data collected. Survey items were based on a literature review, the working experience of the principal researcher - an educator, and the coresearcher, a community health nurse. The questions were open ended and designed to elicit elaboration on teachers' experiences in their elementary classrooms during the 2009 H1N1 influenza outbreak.

Also, the inquiry relied on two other primary sources of data: narrative material and conversational interviews. Thematic analysis of the interviews and surveys was conducted in order to gain phenomenological insights (van Manen, 1997) relevant to the experience of pandemic preparedness by teachers. The analysis was qualitative and interpretive. Teachers participating in the study represented elementary schools from across the local school district in Cape Breton, Nova Scotia, Canada and included teachers of primary grades (kindergarten), one, two, three, as well as elementary grades five and six. No grade four teachers responded to the request to participate.

\section{Background of the Pandemic}

In March 2009, there were a number of respiratory illness outbreaks in Mexico. The virus causing the illness was a unique combination of influenza virus genes never before seen in animals or people. It was identified as influenza A/H1N1. The 2009 world wide outbreak was the second pandemic attributed to the H1N1 influenza virus, the first being the flu pandemic of 1918 known as the Spanish flu (Greger, 2006). Estimates of the loss of life attributed to the Spanish flu are anywhere between 50 and 100 million worldwide 
(Taubenberger \& Morens, 2009). In Canada, it is estimated that 55,000 people succumbed to the flu between the years 1918 and 1919 (Jones, 2007). The 2009 H1N1 virus was a new strain; a re-arrangement of avian, human and swine viruses which resulted in the flu virus now being called "Swine Flu" (Trifonov, Khiabanian \& Rabadan, 2009). In Canada, approximately $10 \%$ of the population were infected with the virus with 428 confirmed deaths (Public Health Agency of Canada, 2012). Not all of those infected with the virus exhibited symptoms of the virus.

On June $11^{\text {th }}$, 2009 the World Health Organization (WHO) declared the new H1N1 influenza virus a pandemic flu generating a phase six alert, the highest level possible to issue (Manitoba Health, 2010). In Canada, pandemic planning and response is guided by several key international frameworks. Like all participating WHO members, Canada is required to meet conditions set out by International Health Regulations (IHRs) which were first adopted in 1969 and recently updated in 2005 in response to the lessons learned from the 2003 SARS ( Severe Acute Respiratory Syndrome ) outbreak (Canadian Senate Committee Reports, 2010). Perhaps most significantly, pandemic preparedness and response in Canada is influenced by the WHO document Pandemic Influenza Preparedness and Response which recommends measures and systems which are deemed appropriate in response to an influenza pandemic. Central to this document is an emphasis on the "whole of society" approach to pandemic planning and preparedness. In this sense, all sectors of society, including government departments, health and nonhealth workers, families and individuals are called to work together to raise awareness, promote accurate information and reduce the spread of the illness through appropriate infection control measures (WHO, 2011).

The first lab confirmed cases of H1N1 influenza were in Nova Scotia on April 26 ${ }^{\text {th }}$, 2009 (Manitoba Health, 2010, p. 1). These cases were announced by Dr. Robert Strang, the Chief Public Health Officer, who reported four students between the ages of 12 and 18 were recovering from a type of influenza attributed to H1N1 infection (CBC News, 2009). From April 2009 to January 2010, there were 1,334 lab-confirmed cases of H1N1 in Nova Scotia (Nova Scotia Summary Report, 2010, p. 3). However, because only the most serious cases were being lab confirmed it is believed many more Nova Scotians were infected with the virus. Between April 2009 and January 2010, the disease resulted in 261 hospitalizations, 50 of which required intensive care treatment, and seven deaths (Nova Scotia Summary Report, 2010, p. 3).

This particular pandemic occurred in two distinct waves. The first H1N1 infections peaked in July 2009 with the second wave peaking in the second week of November of the same year. The beginning of the 2009 school year saw a great number of infections as the second wave was gaining momentum. Particularly important for teachers and school officials was the fact that during the second wave "the rates of lab confirmed cases were highest in children younger than nine years old [while]...hospitalization rates were highest in the under one year age group, followed by those aged one to nine years..." (Nova Scotia Summary Report, 2010, p. 4). 


\section{Pandemic Planning and K-12 Schools}

Pandemic preparedness planning in Nova Scotia did not specifically target schools for any kind of special attention. In this sense they were prepared no differently than other community organizations. The Nova Scotia Pandemic Preparedness Plan in fact grouped schools and school districts with other community agencies such as acute/long term care facilities, workplaces, daycares, sporting venues, public transit as well as others in its planning process. In August 2009, weeks before the second wave of H1N1 hit and just prior to the beginning of the school year, health officials briefed school district superintendents in a presentation titled H1N1: Considerations for P-12 Schools. The presentation was informational in nature. It included an overview of the disease outbreak which had occurred up until August 10th, 2009 as well as a summary of the disease's progression to this point. The idea was reinforced that while the disease was widespread in the community that it was the "younger age groups [which] were most infected" (2009, p. 6). In this presentation, the school board administrators were also given a synopsis of the provincial government's public health plan including: prevention strategies (hand hygiene and cough etiquette), environmental cleaning (cleaning high traffic surfaces such as doorknobs, faucets, sports equipment, keyboards, telephones), and educating janitorial personnel and school bus providers of proper cleaning techniques. Recording reported illnesses and absenteeism rates in excess of $10 \%$, was also suggested in addition to developing a "link with local PHS (Public Health Services) as required" (H1N1: Considerations for P -12 Schools, p. 18). School closure was not recommended by health officials to school board superintendents citing the "significant social and economic costs" of this and "the limited effectiveness since students would congregate elsewhere" (p. 17).

On September $1^{\text {st }}, 2009$ a letter addressed to parents, guardians, and guardians, students and school staff, signed by the Minister of Education Marilyn More and Dr. Robert Strang, Chief Public Health Officer provided an account of pandemic planning as it pertained specifically to K-12 schools in the province. The letter assured the Departments of Education and Health Promotion \& Protection along with school boards and public health agencies "have been working closely together to ensure measures are in place to prevent the spread of H1N1 in schools" (Strang and More, 2009). However, the letter acknowledged the fact that H1N1 was a new and evolving strain "making it difficult to know how it will behave" (Strang and More, 2009). The letter also confirmed that "severe cases are anticipated" and "school aged children in the 5-19 age group will be most affected by H1N1” (Strang \& More, 2009).

\section{Pandemic Planning and the Teachers Union}

The Nova Scotia Teachers Union (NSTU) indicated in an October 2009 newsletter issued to all teachers in the province that it was

... monitoring the H1N1 situation in Nova Scotia, across Canada and around the world. We are continuing to work closely with the provincial 
Department of Education, as well as reviewing updates from the Canadian Teachers Federation (CTF), the Public Health Agency (PHAC), and the World Health Organization (WHO).

In a press release dated October $30^{\text {th }}$, the teachers' union urged the Nova Scotia Department of Health to alter its vaccination strategy to administer the H1N1 vaccine to students and teachers while they are at school. The release quoted NSTU president Alexis Allen,

Students and teachers are on the front line of this pandemic, and yet schools seem to have been left out of the vaccination planning. Schools are an ideal venue for vaccinating our children and their teachers, instead of having them line up for hours before and after school at public arena and community centres. (2009, p. 1)

The second press release came a week later on November $5^{\text {th }}$ and the tone was urgent. This press release called on the Minister of Education to send all pregnant teachers home where they could work with no loss of salary and benefits "until such time as they have been able to receive the H1N1 vaccine and have had sufficient time to have the vaccine reach its full effectiveness" (p. 1). Pregnant women were considered at high risk and were deemed to be a priority group to receive the H1N1 vaccine. Teachers, asserted Allen, are in daily contact with children under 15 years of age - the group at highest risk of H1N1 infection.

\section{Pandemic Planning by Schools and Boards}

In November 2009, the Cape Breton Victoria Regional School Board (CBVRSB) released the document Pandemic Planning (H1N1). The document outlined the school board's response to the pandemic and described the specifics of organizational and operational considerations of its pandemic response plan. Pandemic Planning (H1N1) delineated responsibilities throughout the organization for various aspects of the plan. The CBVRSB Pandemic planning (H1N1) document provided clear direction for school administration and staff, mandating that "each school in the Cape Breton-Victoria Regional School Board was expected to develop an individual school plan to deal with the H1N1 pandemic" (CBVRSB, 2009, p. 8). The document said clear "Action Plans" would be created, "for schools, central office personnel and for each of our work groups, such as, bus drivers, maintenance staff and cleaners. The intent of the action plans is to minimize the spread of the virus by taking specific actions in the workplace (2009, p.8). The Board plan also included a detailed checklist for schools which included: reporting of absenteeism, availability of hand hygiene products, displaying pandemic information, and additional cleaning of hard surfaces and training of custodial staff in additional cleaning requirements and techniques. 


\section{Teachers and the Classroom Experience of Pandemic Response}

As has been demonstrated in the preceding sections on the background of the pandemic, the flow of information, advice, guidelines and policies that directly impacted teachers and children in classrooms moved down through international and national government agencies, provincial health authorities, policy documents and decision makers.

The majority of teachers interviewed and those responding to the survey indicated they felt responsible for infection control practices in their classroom. The role of schools in the transmission and prevention of infectious disease has been written about widely (Stephenson, Barrios, Cordell, Delozier, Gorma, Koenig, Odum, Poider, Randolph, Shimabukuo \& Singelton, 2009; Li, Freedman \& Boyer-Chu, 2009; Patterson, Durrheim \& Tuyl, 2009; Hua, 2010). However, no research is available on teachers' experience of acting as a health protection resource in controlling communicable diseases (Wong, Cheng \& Lo, 2010). Policy documents and guidelines designed to prevent the transmission of H1N1 developed by various agencies on all levels speak, generally, about schools, and predominantly target superintendents, board personnel, and school administrators, but few documents reference the teacher, or the classroom, as being on the frontline of infection control. The organizational authority, the school district and the Pandemic Plan it devised, were primarily focused on providing direction and organization, the technical, managerial, and rational structure for Board office personnel. Directives and recommendations for schools were addressed to principals, whom it was assumed would be the direct communication link for teachers. There is but a single reference to the word "teacher" in the school district's Pandemic Plan and it is in reference to "pre-service teachers" and provides a procedure to contact the university students in case their teaching practicum is disrupted by school closure (CBRVSB, 2009, $\mathrm{p}, 5)$. The lack of any reference to teachers is also the case for other school board pandemic plans in Nova Scotia with the more generic term "staff" or "employees" being used in the documents. In the four school board plans reviewed for this research (Chignecto, 2009; Strait, 2009; South Shore, 2009; CBVRSB, 2009), one plan made direct reference to the word teacher, however, none of the plans directly addressed the roles and responsibilities of teachers in relation to other staff, support staff, or employees.

The survey responses that indicated that teachers felt overwhelming responsible for infection control, and by extension for the health and well being of their students, is not at all surprising when the essential relational characteristic of teaching is taken into consideration. For most elementary school teachers, education is a living process characterized by the personal engagement between an adult teacher and a young child. Parents exercise the primary responsibility for a child's well being and healthy development. Yet, in the reality of modern family circumstances, teachers will often spend as much or more time with children than many parents are able. Children come from a wide range of backgrounds and circumstances and teachers exercise a responsibility known as in loco parentis (in the place of the parent). This concept embodies a unique relationship that supports or flows out of the primary responsibility of the parent. It is a relationship with children that is unique to classroom teachers and 
different from that of other school professionals including; counsellors, psychologists, principals, or other staff and employees such as secretaries, custodians or bus drivers.

Van Manen (1991) states, “...the school as a cultural-political institution needs to come to terms with the in loco parentis responsibilities in the pedagogical relationship" (p. 6). Van Manen (1991) defines pedagogy broadly for its unique relational qualities saying it is "the human charge of protecting and teaching the young to live in this world and to take responsibility for themselves” (p.7). Teachers stand in a relation of care and attention for the children in their classrooms. This means teachers act on behalf of the child by referring to the moral responsibility they bear for the health and well being of the child. The pedagogical relation is a personal relation and it is at the heart of teaching. The atmosphere in schools and classrooms and in individual lessons is determined by the relational atmosphere between teachers and students. This is to recognize that not all relations between teachers and students are positive in a pedagogical sense.

Schools and classrooms must be managed according to organizational principles to ensure standardized approaches and clearly delineated processes and procedures. The management of large school systems requires a type of technical rationality and the school districts' pandemic plans illustrate an approach that requires order and efficiency. However, the rationalized features of a technical and managerial organization must include, and not override, or fail to recognize the pedagogical relationship, the personal, intentional and special responsibility "given" to teachers that is central to the classroom experience for both children and teachers. In the official pandemic planning documents across all levels the teacher and any recognition of the pedagogical relationship is absent.

\section{Teacher Responsibility for Infection Control Practices}

As indicated above, there is no research that looks specifically at the classroom teachers' role in infection control, or how teachers perceive that role. Despite this lack of evidence, best practices, good judgment and common sense have value. As outlined in the first part of this study, schools, primarily through school boards and principals (School Administrators Toolkit, 2009) were given directives, guidelines and procedures to follow to minimize infection. This advice came down through, international, national, and provincial health agencies and represented the most effective infection mitigation practices available at the time.

All eleven (11) teachers surveyed in this study reported that they taught infection control practices to the children in the classroom. But only five (5) felt prepared to fulfill the role of infection control agent. One teacher said,

What do you do? I came to school each day and there they were - twentytwo six and seven year olds and I was responsible for them. Just there looking up at you. At the end of the day, it's not anyone else - just me. They're babies, they put things in their mouths, they share food, supplies, that's life, but with all the H1N1 stuff going on, I'll tell you it was stressful 
trying to ensure they were safe in your classroom and they weren't going to get sick or worse.

The pedagogical relationship is illustrated by the profound sense of responsibility being indicated by this teacher and by other teachers in the study. The responsibility is manifested in caring deeply for the children they teach. Van Manen (2002) has described the phenomenology of "care as worry" in the parent-child relationship and the pervasive concern and anxiety associated with caring for a child. So, too, in the context of pandemic preparedness and response which is fraught with unknown threats and possible transmission of a potentially life threatening influenza, teachers encounter similar experiences of caring responsibility in loco parentis. The teacher above indicates how "stressful" it was to be "responsible" and then acknowledges the children are "just there looking up at you. At the end of the day, it's not anyone else, just me.”

Levinas (1969) describes the original experience of the face-to-face encounter with the other in which I am faced with the vulnerability of the other. Faced with children who are wholly dependent and in possible danger of becoming ill from an unseen virus, the teacher describes her responsibility unequivocally. It is hers and hers alone. It is a demand she did not invite or seek out. The teacher is commanded and describes the experience of the children "just looking up" at her. What is in that look? It is in this sense that Levinas states, "One can say that the face is not seen" (1969, p.86). Levinas removes the face from the category of object and charges it with absolute alterity. He would say the teacher is held hostage by the students' gazes, by the demands the children are making upon her. The faces of the children are not as much perceptual, as they are ethical demands. The skin of the face, Levinas tells us, "is the most naked" (1969, p. 86), a nakedness described in its vulnerability. As naked perhaps as "the babies" the teacher refers to in describing the children in her classroom.

What is the nature of this responsibility the teachers feel? It may be described as a fearing for the other. I fear for the death of the other. The teacher hints at just this when she says her stress is induced by "ensuring they (the children) weren't going to get sick in her classroom or worse." It is this fear that is the origin of responsibility. I fear for the other's suffering. And yet, this demand, this call to responsibility is communicated through the invisible "face." It is a demand made in silence - nothing is said, there is no plaintive call or plea.

\section{The Teacher Exposed by Fear}

Teachers were asked to reflect on the levels of fear and anxiety they may have experienced during the H1N1 pandemic. First, they were asked about how the pandemic and their role as infection control agents affected their perception of their personal well being. Secondly, teachers were asked to describe how they perceived the level of fear and anxiety of the children in their classrooms. Ten (10) of the eleven (11) teachers surveyed indicated they believed teachers were at higher risk of exposure to the H1N1 flu virus and they, personally, felt at higher risk of contracting the virus. Six (6) of the eleven (11) 
teachers said they experienced anxiety about the perception of being at higher risk of exposure to the virus. However, eight (8) of the eleven (11) said they experienced higher levels of concern and anxiety for the children in their classroom during the pandemic outbreak. All eleven (11) participants surveyed said they believed teachers should be considered a high priority group in accessing the vaccine during pandemic outbreak.

The responses elicited by teachers concerning relatively high levels of fear and anxiety build on the theme of responsibility. The pedagogical relation is fundamentally a personal relation and teachers, therefore, feel responsible for the children in their care. The concern in the general population after two highly publicized deaths, the shortfall of available vaccination in the fall of 2009 caused widespread, fear, confusion and frustration in the community at large (Nova Scotia Summary Report, 2010). Teachers assumed the important role of not only needing to maintain infectious control, but it was also their responsibility to assuage the anxiety of parents and students (Wong et al, 2101). Teachers indicated they too were experiencing a range of responses from fear to confusion and anxiety. It is to be expected in this type of unfamiliar situation, that teachers would feel deep levels of worry, fear, concern and anxiety as they were presented with official communications.

The themes of fear and anxiety are found in teachers' responses throughout the study. In responding to how they felt about their responsibility as infection control agents seven (7) of the teachers indicated their fear using terms and phrases such as; "anxious," "anxious how fast H1N1 could spread," “anxious about proper cleaning protocols," "I was in fear," "there was a bit of an anxious feeling around the building," "worried that I would not have sufficient staff..." Teachers who felt unprepared to fulfill the role of infection control agents experienced the highest levels of anxiety and conveyed a sense of the uncontrollability of the situation. Another teacher commented,

No changes were considered by the board to reduce risk to our students. For example assemblies and meetings, concerts where there were big crowds were not cancelled.

This response shows that in the face of the myriad of factors associated with a communicable disease, which include the invisibility of the virus, and the confusion concerning cause, anxiety is produced and as a result, teachers are prone to generate vague perceptions of risk. Another teacher said,

So many variables were out of my control. Simply having accurate contact information for each child was difficult. We were told that if flu symptoms were suspected, parents/guardians had to come to take the child from the school immediately - discreetly - not frightening a child or drawing attention to them. Unfortunately - several parents in my class that year could not consistently afford to keep a phone. We had to talk to them at length and come up with an appropriate way to be able to contact them in a timely manner. It was a frightening time. There was so much unknown. I was afraid for my own health, but what could you do? You had to be 
strong for the kids, not show your fear, just come to work everyday in a classroom where you could get sick. But that's all you could do...

The fear of the unknown, worry, concern and anxiety over a lack of control combined with a deep sense of responsibility resulted in teachers feeling vulnerable, afraid for themselves and their students. The person who fears will normally attempt to avoid what she believes is threatening her life or health. Fear has an intentional object. It is directed at something or someone. And yet, the virus is unseen and unknown. Elias Canetti writes, "There is nothing that man fears more than being affected by something unknown. One wants to see what is reaching out for one, one wants to identify it, or at least place it in a context" (cited in Svendsen, 2008, p. 37). Such a fear of the unknown or the invisible is not an objectless fear. The virus is real, but indefinite, it is potentially everywhere and nowhere, in the air we breathe, on the surfaces we touch, in our bodies, in the bodies of others. While eliciting an indefinite fear it is still very much a fear that something unpleasant or life threatening can occur. The teacher is afraid. She fears for her health, yet her concern and care for the children, her fear for their health and well-being overrides the fear for her own person.

These results on teacher anxiety are important in that they may also reveal a situation in which children are negatively affected in ways previously not forseen. A psychological study conducted in the Netherlands by Remmerswaal and Muris (2010) looked specifically at children's fear reactions to the H1N1 pandemic and the role of information concerning the threat of the flu as it was provided by parents and how this could be associated with children's fear of the disease. While the study looked specifically at parents, it may be constructive to consider its findings in light of the fact that teachers act in loco parentis and that they too indicated a high degree of fear and anxiety.

The study found parents' fear levels of the Swine Flu were sigificantly related to their children's fear level of the disease. Secondly, a significant positive relationship was found between parents' transmission of threat information about the disease and children's fear levels. While the research did not look specifically at teachers, it did find information from the media and from friends were also "uniquely associated with children's fear of the disease” (p. 448). Is it reasonable to assume that elementary classroom teachers, particularly those who feel responsible for being infection control agents, educating children about the disease and its transmission, and who are feeling anxious and fearful may also play a significant role in the development of children's fear?

The idea of fear and anxiety is pervasive in the teacher's lived experience descriptions. The accounts reveal the presence of inner conflict; responsibility for the well being of the children, the unpredictability of the disease, the cleanliness of surfaces, the concern for their personal safety are some of the fears that arise. Anxiety "is afraid" says Kierkegaard, "yet it maintains a sly intercourse with its object, cannot look away from it, and indeed will not...” (May, 1977, p. 42) The planning documents and directives, action plans and cleaning protocols, precise hand washing instructions, and sneezing and coughing etiquette standards coming down from the authorities were attempts to reduce the anxiety by containing and controlling the spread of infection. And 
yet, the extraordinary measures curiously seem to have often had the opposite effect by quickening the fear and heightening the anxiety. Each sniffle, cough, handshake, mindless bringing of the hand to mouth or nose in that present moment represented a danger and could be interpreted as such. The present is dangerous because it leaves us in the moment unprotected from invisible forces. The present moment becomes concentrated, obliterating the past and jeopardizing the future. The danger of the present requires efficiency; hand sanitizer, Kleenex, a mindfulness of our bodies and attention to the proximity of others. I am in a perennial state of readiness in the face of invisible forces.

Such imagined consequences and/or possibilities require a standing state of emergency, a constant readiness that disrupts the flow of time, the continuity of the past, present and future. The future, what may be, becomes the object of the present, the uncertainty, the imagined consequence for which we must be ready. Aristotle writes, "Plainly the things we fear are terrible things, and these are, to speak without qualification, evils; for which reason people even define fear as the expectation of evil" (cited in Svendsen, 2008, p. 43). We humans can fear most things. We are especially good at constructing innumerable imaginary threats. At times anxiety and trepidation well up in me. My daughter is attending a new university in a big city. She does not respond to my repeated calls to her cell phone. My mind leaps, my heart quickens and I push away imagined horrors that infect me. To calm myself I repeat an old adage that captures the human propensity to create imagined threats, "My life has been filled with misfortune, most of which never happened to me.”

In Heidegger's analysis of fear that which is feared is something that has not yet been realized, something dangerous exists and its potential threatens. The feared object, according to Heidegger "radiates harmfulness" (cited in Svendsen, 2008, p. 43). Fear is closely associated with uncertainty. I am exposed. At the same time fear reveals something about me; it also conceals me from myself. Heidegger, too, addresses the nowness of fear. I am captured by the situation and lose something of my freedom. The children are unable to learn, the teacher unable to teach, the uncertainty imposes itself on the present situation. For Heidegger the temporality of fear is an expectant, presentmaking forgetting. And what is forgotten, according to Svendsen (2008) is oneself, or rather one's options. The future and its possibilities are limited as I direct my attention solely to the present threat. It is as if I lose myself to fear.

Anxiety is related to fear, in that it contains the element of expected danger or possible harm. Fear often has a specific object whereas anxiety lacks one. However, this line between fear and anxiety often blurs. The teachers' fears lead to anxieties across a spectrum of contexts and situations. The fear permeates all aspects of classroom life and, as we will see, impacts relationships, learning and the social cohesion of the classroom community. Wittgenstein (in Lurie, 2006) said, “The world of the happy man is different from that of the unhappy man” (p. 150). In the same vein, the world of the anxious, fearful teacher or child is different in much the same way. The classroom, the school become places where danger threatens and we feel insecure. 


\section{Children's Fear as Contagion}

Over half the teachers reported noticing anxiety in children related to the pandemic. Echoing the findings of Remmerswaal and Muris (2010), one teacher implied a parental role in the development of fear in the children in her classroom,

Parents talked to their children at home about risks. Some younger children were afraid they would die. Some actually had sanitizer of their own from home. Some kids actually had wipes to wipe off door knobs. I coach elementary basketball and kids would not shake hands at the end of the game, but bump elbows. It was as if kids were afraid of each other. You never knew who might be carrying the virus and the kids felt this I guess. It was strange.

Other teachers also pointed to the perceived role of the home, community and media in children's fear responses. "Some students were more aware of the virus and germs. Some carried their own hand sanitizer in their backpack." A primary teacher added, "Students were talking about it, hearing it in the news asking if they would die." The impact of rumour and speculation cannot be under estimated according to these teachers,

When one child became ill, the rumor mill worked very quickly and the rest of the children were led to believe that this child had contracted H1N1. This caused some anxiety among the children. The most difficult thing to control were the inaccurate rumors that circulated throughout the community.

Teachers also indicated children worried about getting the flu shot and were "very worried that they might get the flu, they talked about this in class." Two teachers felt that fear negatively affected children's ability to learn, "It's tough to teach beautiful little people who are so afraid of a cough or a sneeze, that they just focus on that." A kindergarten teacher felt, "Students were anxious about the pandemic...some students did not attend school because of fear."

Public health officials have historically struggled and continue to struggle with how to present information to the public that will motivate the population to take the necessary steps to protect themselves and their families while not instilling fear or panic in people (Hua, 2010). It was just this balance that was being questioned in the following statement by a teacher,

The public health nurse gave us the latest information at an information session during an evening at school. Her message was "apocalyptic" and some parents became quite terrified. A few of our parents who happen to be family doctors and were present that evening expressed concern that the words of the health nurse were too dramatic and presented a doomsday rather than a realistic hopeful message. 
Teachers were asked how they responded to children's concerns and anxieties. Most indicated they reinforced good hygienic practice and reassured children they would remain healthy if they followed these practices. "I reinforced with them about how well we were practising our hand washing, coughing procedures, eating well and how healthy we all were." A grade three teacher reported he, "reassured them that our classroom was squeaky clean and that we were doing all we could to reduce risk of infection.” Another teacher recounted,

Those afraid of dieing, I addressed to make sure they knew they were not going to die. I did explain they needed to do things to help not get sick themselves and therefore if everyone did their part, germs would not be spread. (Eat well, get plenty of rest, exercise, and drink water).

Teachers indicated there were many classroom discussions with children and to other teachers who gave additional assistance, "We talked about it as a group - if some one seemed particularly anxious - I phoned home and in some cases spoke with our guidance counsellor.”

In addition to coping with their concerns, their worries and anxiety for children, teachers indicated they also acted as a support for parents who expressed fear and worry. Ten (10) of eleven (11) teachers responded Yes to the question "Did parents/caregivers express concern to you during the time of pandemic flu outbreak?” Teachers related they disseminated information and "available resources from board, public health and online" sources. Two teachers raised a concern about a perceived ethical dilemma they felt added to the tension and increased fear.

A parent called the principal to report that her child had H1N1. The student was in my class. I was told not to tell anyone. Although the staff was told there were cases of $\mathrm{H} 1 \mathrm{~N} 1$ in the school, no one was permitted to say which child or classroom. Were there procedures I needed to take immediately?

Confidentiality and privacy concerns related to parents and the community were raised in this teacher's comment also,

Most parents expressed concern that school would be closed and they didn't know what they would do for childcare. Teachers had a lot of questions about confidentiality - we didn't want to comment upon the status of our school - Parents wanted to know if there were any confirmed cases - we couldn't answer but they were telling us that Facebook was swirling with rumors.

Another teacher related, 
Although it was hush hush...don't speak...students heard from friends about children that became infected with H1N1, and those airlifted to Halifax. As a classroom, we shared the secrets and made little cards... which we sent to the sick children.

The teachers' responses and anecdotes point to fundamental experiences of epidemics and the threat of communicable diseases. Down through history epidemics, or plagues as they were more commonly known, have been formative in human existence. Sophocles' play Oedipus Rex opens with a plague brought on by the transgressions of the King. The Priest reports to King Oedipus "Disease infects the fruit blossoms of our land; disease infects our herds of cattle, makes women in labour lose their children. And deadly pestilence, that fiery god, swoops down to blast the city" (Sophocles, 2005). Individuals, as well as the community at large, suffer. Priscilla Wald's (2008) Contagious: Cultures, Carriers and the Outbreak Narrative argues that down through human history plagues have acted as the "language of god's displeasure" (p. 11) Plagues force authority figures to assume responsibility for their actions and for their people's suffering. The earliest physicians and historians including Hippocrates and Thucydides describe plagues ravaging the social order as much as they did individual bodies.

When a communicable disease makes it dangerous to congregate and life-threatening to tend to the sick, social relationships are jeopardized. The teachers describe children avoiding previously normal social contact with peers out of fear of being infected. Unusual patterns of behaviour arise to disrupt the flow of everyday experience (refusing to shake hands after a ball game, cleaning door knobs with disinfectant, carrying personal bottles of hand sanitizer). Some students refuse to attend school disrupting the social structure of classroom and school, choosing to self isolate rather than be with classmates and friends who are now perceived as potential threats. Wald (2008) carefully examines literary treatments of the disease to illustrate what she terms as a "psychological numbing that results from the fear of others that hastens the dissolution of social organization" (p. 11). Boccaccio's The Decameron (ca. 1350) describes a lack of mourning during a time of outbreak and observes that "no more respect was accorded to the dead people than would nowadays be shown toward dead goats." In Daniel Dafoe's Journal of a Plague Year (1721), the author laments that the "Danger of immediate Death to ourselves, took away all Bowels of Love and Concern for another" (cited in Wald, 2008).

The word contagion means literally, "to touch together" and one of its earliest uses in the fourteenth century referred to the circulation of ideas and attitudes (OED, 2002). The word frequently connoted danger or corruption as in the spread of heretical or revolutionary ideas. The medical use of the word contagion captured the circulation of disease, but the word still retains the circulation of ideas as being both material and experiential, yet at the same time invisible. The teachers' accounts echo this element of contagion in their descriptions of how quickly idle rumour and gossip fuelled by fear and speculation spread. The stories of "other" children falling ill were "difficult to control" and "swirl" about infecting children and parents with fear and anxiety. Both aspects of the word contagious - the spread of disease and "dis-ease" are captured in the experiential descriptions displaying the power and danger of bodies in contact and 
demonstrating the simultaneous fragility and tenacity of social bonds. Today we often hear the phrase "going viral" to describe the spontaneous dissemination of ideas through modern technologies. Fearful rumour spreads digitally, through Facebook, by word of mouth, rippling invisibly throughout the community infecting others with fear, doubt, anxiety and even panic.

The invisibility of the virus results in the object of my fear being the other person. The Other personifies the virus for me, their sniffles, coughs, and uninvited contact is perceived as a threat. Healthy people as potential carriers make the fear ubiquitous and make visible the contact that I did not know I previously had, or the items that I share and the spaces I frequent. The known carriers, who may unwittingly cause or contribute to an outbreak, are to be shunned and isolated. Any child who displays any symptom is to be sent home on the bus or taken away by parents. In this particular case, some children who became ill were taken out of the community and "airlifted to Halifax." But the carriers' identities were shrouded in secrecy and breathed in hushed tones. The children and teachers are forbidden to speak the name of the infected person. The rituals of cleanliness and social distancing act as a ward against the invisible threat and the destructive potential of the other. It is only when the infected children are safely out of the community and no longer pose a threat that "we shared the secrets and made little cards... which we sent to the sick children.”

\section{Conclusion}

Pandemic preparedness and response at the national, provincial and local levels could benefit from ongoing research designed to better understand the experiences and function of classroom teachers to ensure that they, who play a vital role in the efficacy of pandemic response efforts, have the levels of support and education they require. It is important to recognize that pandemic planning documents in Nova Scotia do not specifically address the role of classroom teachers or target schools for special attention different from other community organizations. This represents an important omission and a potential serious weakness in a communication strategy. As this study has shown, elementary classroom teachers are key people in the overall efficacy of any pandemic plan as they act as infection control agents, teach preventative hygiene techniques, help maintain hygienic environments to mitigate the spread of the disease and provide information and advice to parents and community members. But perhaps even more importantly they care for children who are often those most vulnerable to infection. Teachers perform these key functions, yet pandemic planning documents do not recognize or address the important responsibilities they assume.

Elementary teachers are on the frontline of pandemic response and need to be central to health and educational efforts to prepare, educate and provide training for those in contact with a high number of vulnerable populations. Understanding how elementary teachers experience this role through phenomenological research is important. Further research is required on the experiences of secondary teachers and school principals at all grade levels. A clearer understanding of how influenza intervention and preparedness is 
experienced by teachers provides important insights which can contribute to future pandemic preparedness strategies.

The authors acknowledge the research funding provided by the Cape Breton Health Research Center without which this study would not have been possible.

\section{References}

Cape Breton Victoria Regional School Board. (2009). H1N1 pandemic plan. Retrieved from http://www.cbv.ns.ca/welcome/uploads/H1N1/Pandemic\%20Plan.pdf

Cauchemez, S., Ferguson, N., Wachtel, C., Tegnell, A., Saour, G., Duncan, B., Nicoll, A. (2009). Closure of schools during influenza pandemic. The Lancet, 9, 473 -481.

CBC News (2009). Officials confirm six cases of swine flu in Canada. Retrieved from http://www.cbc.ca/news/canada/story/2009/04/26/mexico-swine-flu.html

Chignecto - Central Regional School Board. (2009). Pandemic influenza plan. Retrieved from http://ccrsb.ca/sites/default/files/CCRSB\%20Pandemic\%20Influenza\%20Plan.pdf

Greger, M. (2006). Bird flu: A virus of our own hatching. New York, NY: Lantern Books.

Hua, V. (2010). Scare tactics. $T$ H E Journal, 37, 2, 20-25.

Jones, E. (2007). Influenza 1918: Disease, death and struggle in Winnipeg. Toronto, ON: University of Toronto Press.

Levinas, E. (1969). Totality and Infinity (A.Lingis, Trans). The Hague: Matinus Nijhoff.

Li, C., Freedman, M., \& Boyer-Chu, L. (2009). Championing school-located influenza immunization: The school nurse's role [Supplement 1,18S- 28S]. Journal of School Nursing, 25.

Luria, Y. (2006). Tracking the meaning of life: A philosophical journey. Columbia, MO: University of Missouri Press.

Manitoba Health. (2010). H1N1 Flu in Manitoba: Manitoba's response lessons learned. Winnipeg, MB: Government of Manitoba.

May, R. (1977). The meaning of anxiety. New York, NY: W.W. Norton.

Nova Scotia Department of Health Promotion and Protection. (2010). Nova Scotia's response to H1N1: Summary report. Retrieved from http://www.gov.ns.ca/hpp/publications/H1N1-Summary-Report.pdf 
Nova Scotia Department of Health Promotion and Protection. (2009). H1N1: considerations for P -12 schools. Power point presentation to Nova Scotia school board superintendents. August 17, 2009.

Nova Scotia Department of Health Promotion and Protection. (2008). Nova Scotia health system pandemic influenza plan. Government of Nova Scotia.

Nova Scotia Health Promotion and Protection. (2009). H1N1 (human swine influenza) and seasonal influenza school administrators toolkit. Retrieved from http://www.ednet.ns.ca/h1n1_toolkits.shtml

Nova Scotia Teachers Union. (2009). Watching H1N1- Human swine influenza. The Teacher, 48 (2), 10.

Nova Scotia Teachers Union. (2009). NSTU wants H1N1 vaccine clinics in schools: Press release. October 30, 2009.

Nova Scotia Teachers Union. (2009). NSTU president wants N.S. minister to send pregnant teachers home. Press release. November 5th, 2009.

Oxford English Dictionary. (2002). Oxford University Press.

Patterson, B., D. Durrheim, F. Tuyl (2009). Influenza: H1N1 goes to school. Science, 326, $1071-1072$.

Public Health Agency of Canada. (2012). Influenza. Retrieved from http://www.phacaspc.gc.ca/influenza/index-eng.php

Public Health Agency of Canada. (2010). Public health guidance for post secondary and boarding schools regarding the prevention and management of influenza-like illness (ILI), including the pandemic (H1N1) 2009 influenza virus. Retrieved from http://www.phac-aspc.gc.ca/alert-alerte/h1n1/hp-ps/psili-eng.php

Remmerswaal, D., \& Muris, P. (2011). Children's fear reactions to the 2009 Swine Flu pandemic: The role of threat information as provided by parents. Journal of Anxiety Disorders, 25, 444 - 449.

Sophocles. (2005). Oedipus the King. New York, NY: Simon \& Schuster.

South Shore Regional School Board. (2009). South Shore regional school board pandemic influenza plan. Retrieved from http://www.ssrsb.ca/

Stevenson, E., Barrios, L., Cordell, R., Delozier, D., Gorman, S., Koenig, L., Odom, E., Poider, J., Randolph, J., Shimabukuro, T., \& Singleton, C. (2009). Pandemic influenza planning: Addressing the needs of children. American Journal of Public Health, 99, 255-260. 
Strait Regional School Board. (2009). H1N1 pandemic plan. Retrieved from http://lsstrait.ednet.ns.ca/srsb/SRSBoard/-August-26-09-final.pdf

Strang, R., \& More, M. (September 1, 2009) Letter to parents, guardians, students and staff. Education: Office of the Minister. Government of Nova Scotia.

Standing senate committee on social affairs, science and technology. (2010). Canada's response to 2009 H1N1 influenza pandemic. Ottawa, ON: Canadian senate reports.

Svendsen, L. (2008). A philosophy of fear. London, UK: Reaktion Books.

Trifonov, V. H. Khiabanian and R. Rabadan (2009). Geographic dependence, surveillance and origins of the 2009 influenza A (H1N1) virus. New England Journal of medicine. 361(2). 115-9.

Taubenberger, J., \& Morens, D. (2006). 1918 influenza: The mother of all pandemics. Centers for Disease Control and Prevention. Retrieved from www.cdc.gov/ncidod/eid/vol12no1/05-0979.htm

Wald, P. (2008). Contagion: Cultures, carriers and outbreak narrative. Durham, NC: Duke University Press.

Wong, E., Cheng, M., \& LO, S. (2010). Teachers' risk perception and needs in addressing infectious disease outbreak. The Journal of School Nursing, 26, 398406.

World Health Organization. (2011). Pandemic influenza preparedness: Framework for sharing influenza viruses and access to vaccines and other benefits. Retrieved from http://www.who.int/influenza/resources/pip_framework/en/index.html

van Manen, M. (2002). Care - as-worry, or “Don’t worry be happy.” Qualitative Health Research, 12, (2), 262-278.

van Manen, M. (1997). Researching lived experience. Human science for an action sensitive pedagogy. London, ON: Althouse Press.

van Manen, M. (1991). The tact of teaching. The meaning of pedagogical thoughtfulness. London, ON: Althouse Press. 